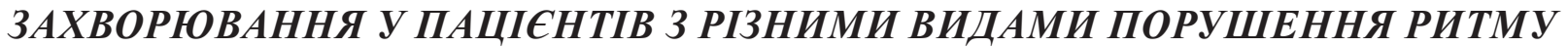
СЕРЦЯ

\author{
О.Ю. Полішук, Т.М. Амеліна, Н.Я. Жиряда
}

Буковинський державний медичний університет, м. Чернівці, Україна

Ключові слова:

психологічні

особливості

особистості,

внутрішня картина

захворювання, якість життя пацієнтів,

порушення ритму серияя.

Буковинський медичний вісник. T.25, № 2 (98).

C. 94-100.

DOI: $10.24061 / 2413-$ 0737.XXV.2.98.2021.15

E-mail: kt482@ ukr.net, amelina. tetiana@bsmu.edu.ua, nataliazhyryada@gmail. com
Мета роботи - дослідити психологічні особливості особистості, характеристику внутрішньої картини захворювання та якості жсття у пацієнтів з порушеннями ритму серия.

Матеріал і методи. Обстежено 352 пацієнти, яких розподілено на чотири групи залежно від виду порушення ритму серця: екстрасистолія (часта - понад 30 за 1 год), фібриляція передсердь, пароксизмальні тахікардії та порушення провідності імпульсу, які супроводжуються брадикардією (синоатріальні та атріовентрикулярні блокади та синдром слабкості синусового вузла). Усім пацієнтам проведено комплексне психодіагностичне дослідження з використанням Торонтської шкали алекситимії, икали особистісної та реактивної тривожності Спілбергера-Ханіна, госпітальної шкали тривоги та депресї HADS, опитувальника депресї, тривоги та стресу DASS-21, опитувальника діагностики ворожих та агресивних реакцій Басса-Дарки, методики психологічної діагностики ставлення до хвороби ЛОБІ, опитувальника рівня суб'єктивного контролю Д. Роттера та тесту диспозиційного оптимізму.

Результати. Встановлено, щзо при однаковому рівні особистісної тривожності пацієнти із фібриляцією передсердь та життєво небезпечними блокадами серия демонструють високі рівні ситуативної тривожності та депресії. Показник індексу агресивності виявився максимальним у пацієнтів з брадиаритміями та пароксизмальними тахікардіями. В усіх досліджуваних групах пацієнтів із порушеннями ритму серия частіше трапляється гармонійний, тривожний та сенситивний типи відношення до хвороби. Низькі значення інтернальності в галузі здоров'я спостерігаються у пацієнтів із екстрасистолією та особливо у хворих із фібриляцією передсердь. Тест диспозииійного оптимізму виявив середній рівень оптимізму серед пацієнтів з екстрасистолією та пароксизмальними тахікардіями, низький рівень у випадку пацієнтів із фібриляцією передсердь та порушень провідності серия.

Висновок. У результаті проведення комплексного психодіагностичного дослідження визначені психологічні особливості особистості та тип відношення до хвороби у пацієнтів із різними видами порушення ритму серияя. Вказані відмінності формують відповідну внутрішню картину захворювання, яка повинна враховуватись при плануванні лікувальних та реабілітаційних заходів.

ПСИХОЛОГИЧЕСКИЕ ОСОБЕННОСТИ ЛИЧНОСТИ И ВНУТРЕННЯЯ КАРТИНА ЗАБОЛЕВАНИЯ У ПАЦИЕНТОВ С РАЗЛИЧНЫМИ ВИДАМИ НАРУШЕНИЙ РИТМА СЕРДЦА

\author{
О.Ю. Полищук, Т.Н. Амелина, Н.Я. Жиряда
}

Цель работы - исследовать психологические особенности личности, характеристику внутренней картины заболевания и качества жизни у пациентов с нарушениями ритма сердия. 
Original research

Ключевые слова:

психологические

особенности личности,

внутренняя картина

заболевания, качество

жизни пациентов,

нарушения ритма

сердия.

Буковинский медицинский вестник. T.25, № 2 (98). C. 94-100.
Материал и методы. Обследовано 352 пачиента, которые распределены на четыре группы в зависимости от вида нарушения ритма сердиа: экстрасистолия (частая - более 30 за 1 час), фибриллячия предсердий, пароксизмальные тахикардии и нарушение проводимости импульса, сопровождаюшиеся брадикардией (синоатриальная блокада, синдром слабости синусового узла). Всем пациентам проведено комплексное психодиагностическое исследование с использованием Торонтской шкаль алекситимии, шкальг личностной и реактивной тревожности Спилбергера-Ханина, госпитальной шкаль тревоги и депрессии HADS, опросника депрессии, тревоги и стресса DASS-21, опросника диагностики вражеских и агрессивных реакций Басса-Дарки, методики психологической диагностики отношения к болезни ЛОБИ, опросника уровня субъективного контроля Д. Роттера и теста диспозиционного оптимизма.

Результаты. Установлено, что при одинаковом уровне личностной тревожности пациенты с фибриллячией предсердий и жизненно опасными блокадами сердиа демонстрируют высокие уровни ситуативной тревожности и депрессии. Показатель индекса агрессивности оказался максимальным у пациентов с брадиаритмией и пароксизмальной тахикардией. Во всех исследуемых группах пациентов с нарушениями ритма сердиа чаще встречается гармоничный, тревожный и сенситивный типы отношения $\kappa$ болезни. Низкие значения интернальности в области здоровья наблюдаются у пациентов с экстрасистолией и, особенно, у больных с фибрилляцией предсердий. Тест диспозичионного оптимизма обнаружил средний уровень оптимизма среди пащиентов с экстрасистолией и пароксизмальной тахикардией, низкий уровень в случае пациентов с фибрилляиией предсердий и нарушениями проводимости сердия.

Вывод. В результате проведения комплексного психодиагностического исследования определены психологические особенности личности и тип отношения к болезни у паџиентов с различными видами нарушения ритма сердиа. Указанные различия формируют соответствуюшую внутреннюю картину заболевания, которая должна учитываться при планировании лечебных и реабилитачионных мероприятий.

\title{
PSYCHOLOGICAL CHARACTHERISTICS OF PERSONALITY AND INTERNAL PATTERN OF THE DISEASE IN PATIENTS WITH DIFFERENT TYPES OF HEART RHYTHM DISORDERS
}

\author{
O.Yu. Polishchuk, T.M. Amelina, N.Ya. Zhyriada
}

Key words: psychological personality traits, internal pattern of the disease, quality of life of patients, heart rhythm disorders.

Bukovinian Medical Herald. V.25, № 2 (98). P. 94-100.
Abstacts. We investigated psychological characteristics: anxiety, depression rate, hostility and aggression, subjective control level, dispositional optimism, and types of attitude to the disease in patients with different types of heart rhythm disorders.

Objective. To determine psychological characteristics of personality, characteristics of the internal pattern of the disease, and quality of life in patients with different types of heart rhythm disorders.

Results. 352 patients were examined. They were divided into 4 groups depending on the type of heart rate disorders: extrasystole (frequent-over 30 per 1 hour), atrial fibrillation, paroxysmal tachycardia, and deterioration of impulse conductivity, accompanied by bradycardia (sinoatrial block and sinus node dysfunction syndrome). All patients underwent a comprehensive psychodiagnostic study using the Toronto Alexithymia Scale, the Spielberger-Khanin Personal and Reactive Anxiety Scale, the Hospital Anxiety and Depression Scale (HADS), 
the Depression, Anxiety and Stress Questionnaire (DASS-21), the Bass-Darky test for aggressiveness and hostility diagnostics, study of the type of attitude to the disease (LOBI), the Rotter's Locus of Control Scale and the Dispositional Optimism Scale. It was found that with the same level of personality anxiety, patients with atrial fibrillation and life-threatening heart block demonstrated high levels of situational anxiety and depression. The index of aggression was the highest in patients with bradyarrhythmias and paroxysmal tachycardias. Harmonious, anxious and sensitive types of attitude to the disease are more common within all studied groups of patients with cardiac arrhythmias. Low levels of internality in health are observed in patients with extrasystole, especially in patients with atrial fibrillation. The Dispositional Optimism Test demonstrated a medium level of optimism among patients with extrasystole and paroxysmal tachycardia and a low level in patients with atrial fibrillation and cardiac conduction disorders.

Conclusion. As a result of a comprehensive psychodiagnostic study, the psychological characteristics of the individual and the type of attitude to the disease in patients with various types of cardiac arrhythmias were determined. Mentioned disparities form the relevant internal pattern of the disease, which should be taken into account when planning treatment and rehabilitation measures.

Вступ. Останніми десятиліттями психологічні, зокрема, особистісні чинники розвитку серцево-судинних захворювань активно вивчються $з$ тим, щоб на рівні 3 іншими - біологічними, генетичними, демографічними, екологічними, соціальними тощо бути врахованими й у процесі лікування, і для профілактики патології серцево-судинної системи $[1,2,3]$.

Одним із поширених патологічних станів серцево-судинної системи є порушення серцевого ритму. Етіологічні чинники аритмій надзвичайно різноманітні. Порушення ритму серця може бути ускладненням артеріальної гіпертензії, ішемічної хвороби серця, цукрового діабету, захворювань щитовидної залози та інших розладів ендокринної системи, порушення мозкового кровообігу, наслідком стресу, вживання надмірної кількості алкоголю, застосування деяких лікарських засобів тощо $[4,5]$.

Досягнення в галузі нейронауки за останні роки беззаперечно свідчать про патофізіологічні взаємозв'язки між афективними, вегетативними та серцево-судинними системами $[6,7]$. Сьогодні залишається поза сумнівом, що негативні емоції, настрої та пов'язані 3 ними особистісні риси (наприклад, тривожність, злість та депресивні фенотипи) можуть впливати на ризик серцево-судинних розладів та їх прогресування через периферійні фізіологічні зміни, викликані стресовим чи іншим несприятливим досвідом $[8,9,10]$.

Мета роботи. Дослідити психологічні особливості особистості та внутрішню картину захворювання у пацієнтів із порушеннями ритму серця.

Матеріал і методи. Обстежено 352 хворих, які перебували на лікуванні у Чернівецькому обласному клінічному кардіологічному центрі. Усіх пацієнтів, які взяли участь у дослідженні, розподілено на чотири групи залежно від виду порушення ритму серця: 1-ша група екстрасистолія (часта - понад 30 за 1 год за результатами добового моніторування за Холтером), 160 пацієнтів, 2-га - фібриляція передсердь (2a - пароксизмальна і персистувальна, 26 - постійна), 120 хворих, 3-тя - пароксизмальні тахікардії (надшлуночкові та шлуночкові), 49 пацієнтів, та 4-та - порушення проведення імпульсу, які супроводжуються брадикардією (синоатріальні та атріовентрикулярні блокади та синдром слабкості синусового вузла), 23 особи. Групи пацієнтів залежно від виду порушення ритму мали певні відмінності за віком та статтю. Середній вік пацієнтів з екстрасистолією становив 47,66 1,22, пацієнти з фібриляцією передсердь були найстаршими за віком - 63,01 $\pm 0,88$, пацієнти з пароксизмальними тахікардіями виявились наймолодшою групою - 42,73 $\pm 1,82$, пацієнти з брадиаритміями мали середній вік - 60,18 33,25 року. Частка жінок у групі пацієнтів 3 фібриляцією передсердь була найнижчою (39 осіб, 32,50\%), у групі брадиаритмій - 10 осіб (43,48\%), у групі екстрасистолій - 75 осіб (46,87\%), пароксизмальних тахікардій - 23 особи (46,94\%). Усім пацієнтам проведено комплексне психодіагностичне дослідження з використанням Торонтської шкали алекситимії, шкали особистісної та реактивної тривожності Спілбергера-Ханіна, госпітальної шкали тривоги та депресії HADS, оптитувальника депресії, тривоги та стресу DASS-21, опитувальника діагностики ворожих та агресивних реакцій Басса-Дарки, методики психологічної діагностики ставлення до хвороби ЛОБІ, опитувальника рівня суб' єктивного контролю Д.Роттера, тесту диспозиційного оптимізму [11].

Відмінність між середніми значеннями груп перевіряли за допомогою дисперсійного аналізу Фішера.

Результати дослідження та їх обговорення. У результаті проведеного дослідження встановлено, що рівень алекситимії переважав у пацієнтів з фібриляцією передсердь - 70,85 $\pm 0,96$ бала порівняно $з$ пацієнтами з брадиаритміями $-69,18 \pm 2,41$, групи пацієнтів 3 
Original research

екстрасистолією - 67,07 $\pm 0,95$ та пароксизмальними тахікардіями - 66,71 $\pm 1,53$ бала $(\mathrm{p}=0,034)$. Ймовірно така відмінність зумовлена більшою часткою чоловіків у групі пацієнтів 3 фібриляцією передсердь.

Рівень особистісної тривожності за результатами використання опитувальника Спілбергера-Ханіна в дослі-

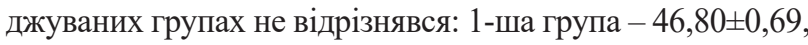

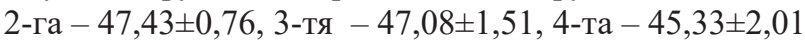
$(\mathrm{p}=0,725)$. Показник ситуативної тривожності за вказаним опитувальником мав тенденцію до збільшення у пацієнтів з брадиаритміями $(50,19 \pm 1,98)$ та фібриляцією передсердь $(47,11 \pm 0,76)$ порівняно 3 хворими 1-ї $(45,23 \pm 0,79)$ та 3-ї групи $(45,77 \pm 1,44), \mathrm{p}=0,101$.

За результатами опитувальника HADS показник тривожності був максимальним у пацієнтів із порушеннями провідності серця - 9,77 $\pm 0,68$ та фібриляцією передсердь - 8,71 $\pm 0,26$ порівняно з групою хворих 3

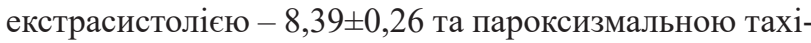

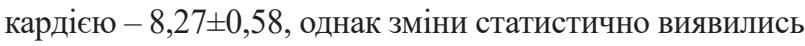
недостовірними ( $\mathrm{p}=0,331)$. Аналогічна тенденція до збільшення рівня тривожності у пацієнтів саме 4-ї групи отримана й у випадку використання опитувальника DASS-21 $(\mathrm{p}=0,661)$.

За результатами аналізу опитувальника госпітальної шкали тривожності та депресії встановлено достовірне збільшення рівня депресії у пацієнтів з фібриляцією передсердь - 7,91 $\pm 0,32$ та порушеннями провідності серця $-7,41 \pm 0,80$ ( $\mathrm{p}=0,004)$.

Максимальний рівень депресії у групі пацієнтів із брадиаритміями встановлено при використанні опитувальників DASS-21та PHQ-9, однак вказані відмінності виявились статистично незначимими $(\mathrm{p}=0,714$ та $\mathrm{p}=0,262$, відповідно).

Результати аналізу опитувальника діагностики агресивних та ворожих реакцій Басса-Дарки (непрямої агресії) виявився найбільшим у пацієнтів з екстрасистолією $(4,88 \pm 0,19)$ та пароксизмальною тахікардією $(4,70 \pm 0,36)$, найнижчим - у хворих із брадиаритміями $(4,00 \pm 0,79)$, $(\mathrm{p}=0,038)$. Натомість у пацієнтів із порушеннями провідності встановлено максимальний рівень показника роздратування - 6,14 $\pm 1,08$ порівняно 3 пацієнтами із пароксизмальними тахікардіями - 5,96 $\pm 0,34$, екстрасисто-

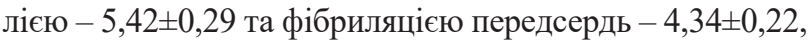
зміни виявились статистично значимими $(\mathrm{p}=0,002)$. Рівень вербальної агресії також мав максимальний

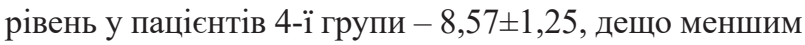
у 3 -й групі - $8,35 \pm 0,47$, проміжне значення показника зафіксовано у пацієнтів з екстрасистолією - 7,72 $\pm 0,24$, найнижчу вербальну агресію демонстрували пацієнти із фібриляцією передсердь $-6,63 \pm 0,23$ ( $\mathrm{p}=0,003)$. Індекс ворожості в досліджуваних групах не мав достовірних розбіжностей $(\mathrm{p}=0,531)$. Показник індексу агресивності виявився максимальним у пацієнтів з брадиаритміями та пароксизмальними тахікардіями $(\mathrm{p}=0,002)$.

Пацієнти з порушеннями ритму серця залежно від виду аритмії демонстрували різні типи відношення до хвороби. Гармонійний тип відношення до хвороби найчастіше траплявся у пацієнтів із фібриляцією передсердь - у 43,33\% випадків, рідше гармонійний тип демонстрували хворі з екстрасистолією - 35,63\%, пароксизмальною тахікардією - 20,41\% та порушеннями провідності серця - 17,39\% ( $=0,001)$ (таблиця). Тривожний тип відношення до хвороби демонстрували від 35,83\% пацієнтів із фібриляцією передсердь

Тип відношення до хвороби (методика ЛОБІ) у паціснтів 3 порушеннями ритму серця залежно від виду аритмії

\begin{tabular}{|c|c|c|c|c|c|c|c|c|c|}
\hline \multirow{2}{*}{$\begin{array}{c}\text { Тип відношення } \\
\text { до хвороби }\end{array}$} & \multicolumn{2}{|c|}{ Екстрасистолія } & \multicolumn{2}{|c|}{$\begin{array}{c}\text { Фібриляція } \\
\text { передсердь }\end{array}$} & \multicolumn{2}{c|}{$\begin{array}{l}\text { Пароксизмаль- } \\
\text { на тахікардія }\end{array}$} & \multicolumn{2}{|c|}{ Брадиаритмії } & \\
\cline { 2 - 11 } & $\mathrm{n}$ & $\%$ & $\mathrm{n}$ & $\%$ & $\mathrm{n}$ & $\%$ & $\mathrm{n}$ & $\%$ & $\mathrm{p}$ \\
\hline Гармонійний & 57 & $35,63 \pm 3,79$ & 52 & $43,33 \pm 4,52$ & 10 & $20,41 \pm 5,76$ & 4 & $17,39 \pm 7,90$ & 0,0007 \\
\hline Тривожний & 46 & $28,75 \pm 3,58$ & 43 & $35,83 \pm 4,38$ & 12 & $24,49 \pm 6,14$ & 5 & $21,74 \pm 8,60$ & 0,0610 \\
\hline Іпохондричний & 12 & $7,50 \pm 2,08$ & 18 & $15,00 \pm 3,26$ & 1 & $2,04 \pm 2,02$ & 2 & $8,69 \pm 5,88$ & 0,0041 \\
\hline Меланхолійний & & & 1 & $0,83 \pm 0,83$ & & & 1 & $4,34 \pm 4,25$ & \\
\hline Апатичний & 14 & $8,75 \pm 2,23$ & 10 & $8,33 \pm 2,52$ & 4 & $8,16 \pm 3,91$ & 3 & $13,04 \pm 7,02$ & 0,4489 \\
\hline Неврастенічний & 28 & $17,50 \pm 3,00$ & 35 & $29,17 \pm 4,15$ & 8 & $16,33 \pm 5,28$ & 1 & $4,34 \pm 4,25$ & 0,0011 \\
\hline Обсесивно-фобічний & 13 & $8,13 \pm 2,16$ & 18 & $15,00 \pm 3,26$ & 9 & $18,37 \pm 5,53$ & 1 & $4,34 \pm 4,25$ & 0,0103 \\
\hline Сенситивний & 58 & $36,25 \pm 3,80$ & 35 & $29,17 \pm 4,15$ & 10 & $20,41 \pm 5,76$ & 2 & $8,69 \pm 5,88$ & 0,0014 \\
\hline Егоцентричний & 25 & $15,63 \pm 2,87$ & 21 & $17,50 \pm 3,47$ & 7 & $14,29 \pm 5,00$ & 2 & $8,69 \pm 5,88$ & 0,2685 \\
\hline Ейфоричний & 43 & $26,88 \pm 3,50$ & 23 & $19,17 \pm 3,59$ & 2 & $4,01 \pm 2,83$ & 1 & $4,34 \pm 4,25$ & 0,0001 \\
\hline Анозогнозичний & 27 & $16,88 \pm 2,96$ & 18 & $15,00 \pm 3,26$ & 6 & $12,24 \pm 4,68$ & 3 & $13,04 \pm 7,02$ & 0,3847 \\
\hline Ергопатичний & 44 & $27,50 \pm 3,53$ & 31 & $25,83 \pm 4,00$ & 8 & $16,33 \pm 5,28$ & 3 & $13,04 \pm 7,02$ & 0,0381 \\
\hline Паранояльний & 21 & $13,13 \pm 2,67$ & 28 & $23,33 \pm 3,86$ & 6 & $12,24 \pm 4,68$ & 5 & $21,74 \pm 8,60$ & 0,0124 \\
\hline Всього & 160 & & 120 & & 49 & & 23 & & \\
\hline
\end{tabular}


до 21,74 \% хворих із порушеннями провідності серця $(\mathrm{p}=0,061)$. Іпохондричний тип відношення до хвороби також частіше виявлявся у пацієнтів із фібриляцією передсердь $-15,00 \%(p=0,004)$. Меланхолійний тип відношення до хвороби не притаманний пацієнтам із порушеннями ритму серця, такий тип траплявся лише у двох пацієнтів - одного з 2-ї групи, одного - 3 4-ї. Апатичний тип відношення до хвороби траплявся однаково часто - від 8,16\% при пароксизмальній тахікардії до $13,04 \%$ при брадиаритміях ( $=0449)$. Неврастенічний тип відношення до хвороби достовірно частіше виявляли при фібриляції передсердь - 29,17\%, рідше за усі інші нозології при порушеннях провідності серця - 4,34\% $(\mathrm{p}=0,0011)$. Обсесивно-фобічний тип відношення до хвороби у більшій мірі був притаманний пацієнтам із пароксизмальними тахікардіями - 18,37\% та фібриляцією передсердь - 15,00\% порівняно з хворими 1-ї-8,13\% та 4-ї-4,34\% груп ( $\mathrm{p}=0,01)$. Сенситивний тип виявився найчастішим серед усіх типів, які реєструвались у пацієнтів з екстрасистолією - 36,25\% і достовірно частіше траплявся порівняно 3 пацієнтами з іншими видами порушень ритму серця ( $\mathrm{p}=0,0014)$. Егоцентричний та анозогнозичний типи серед представлених нозологій виявляли практично з однаковою частотою від 8,69\% при брадиаритміях до 17,50\% при фібриляції передсердь для егоцентричного типу ( $\mathrm{p}=0,269)$ та від 12,24\% при пароксизмальних тахікардіях до 16,88\% при екстрасистолії для анозогнозичного типу $(\mathrm{p}=0,385)$.

Ейфоричний тип виявлено в понад чверті пацієнтів 3 екстрасистолією - 26,88\% порівняно з пацієнтами 3 фібриляцією передсердь та особливо у випадку пароксизмальної тахікардії та брадиаритмій, де частка таких реакцій не перевищувала 5 \% $(\mathrm{p}<0,001)$.

Ергопатичний тип траплявся досить часто при екстрасистолії - 27,50\% та фібриляції передсердь - 25,83\% та дещо рідше при пароксизмальній тахікардії - 16,33\% та порушеннях провідності серця - 13,04\% ( $\mathrm{p}=0,038)$. Досить високою виявилась частота паранояльного типу рекції на хворобу при фібриляції передсердь -23,33\% та брадиаритміях $-21,74 \%$ порівняно з іншими нозологічними формами аритмій $(\mathrm{p}=0,012)$. Прикметно, що пацієнти із фібриляцією передсердь досить часто демонстрували змішані типи реакції на захворювання, наприклад, гармонійна та ергопатична, тривожна та сенситивна, обсесивно-фобічна та паранояльна тощо.

За результатами оцінки опитувальника Роттера у досліджуваних групах визначався рівень суб'єктивного контролю в різних сферах життєдіяльності. Показник інтернальності в галузі досягнень у всіх нозологічних групах був більшим за нормативне значення п'ять балів, що свідчить про інтернальний тип суб'єктивного контролю, максимальні значення за цією шкалою зафіксовано у пацієнтів з пароксизмальними тахікардіями $(6,73 \pm 0,33)$ та брадиаритміями $-6,91 \pm 0,51(\mathrm{p}=0,003)$ на відміну від інтернальності в галузі виробничих відносин, де пацієнти усіх груп демонстрували екстернальний тип суб'єктивного контролю ( $\mathrm{p}=0,155)$. Аналогічно до сфери досягнень інтернальний тип для усіх пацієнтів незалежно від виду аритмії демонстрували пацієнти щодо інтернальності у сфері міжособистих відносин $(\mathrm{p}=0,091)$. Характерною особливістю пацієнтів 3 фібриляцією передсердь виявились найнижчі серед обстежених груп залежно від виду аритмії значення показників інтернальності стосовно усіх сфер життєдіяльності за винятком галузі міжособистих відносин. Привертають увагу низькі значення інтернальності в галузі здоров'я у пацієнтів із екстрасистолією $(4,00 \pm 0,46)$ та особливо у хворих з фібриляцією передсердь $(3,21 \pm 0,97)$ порівняно 3 пацієнтами із пароксизмальними тахікардіями,

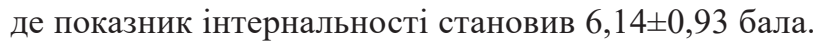
Високий рівень суб' єктивного контролю саме у пацієнтів 3-ї групи ймовірно зумовлений тією обставиною, що значну частку цієї групи становили пацієнти із надшлуночковою пароксизмальною тахікардією та, відповідно, можливістю пацієнта самостійного відновлення ритму за допомогою вагусних прийомів.

Тест диспозиційного оптимізму виявив середній рівень оптимізму серед пацієнтів 1-ї та 3-ї груп $(23,12 \pm 0,92$ та $24,62 \pm 1,70$ бала) та низький у випадку пацієнтів із фібриляцією передсердь - 19,48 1 1,08 та порушень

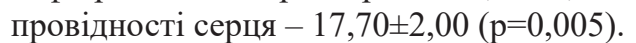

\section{Висновки}

У результаті проведеного дослідження встановлено, що при однаковому рівні особистісної тривожності пацієнти із фібриляцією передсердь та життєвонебезпечними блокадами серця демонструють високі рівні ситуативної тривожності та депресії.

Рівень непрямої агресії виявився найбільшим у пацієнтів з екстрасистолією та пароксизмальною тахікардією, у пацієнтів із порушеннями провідності встановлено максимальний рівень показника роздратування. Рівень вербальної агресії також мав максимальний рівень у пацієнтів з порушеннями провідності. Таким чином показник індексу агресивності виявився максимальним у пацієнтів з брадиаритміями та пароксизмальними тахікардіями.

В усіх досліджуваних групах пацієнтів із порушеннями ритму серця частіше трапляється гармонійний, тривожний та сенситивний типи відношення до хвороби;

Низькі значення інтернальності в галузі здоров’я спостерігаються у пацієнтів з екстрасистолією та особливо у хворих з фібриляцією передсердь, на відміну від пацієнтів із пароксизмальними тахікардіями, де показник рівня суб'єктивного контролю мав максимальне значення.

Тест диспозиційного оптимізму виявив середній рівень оптимізму серед пацієнтів з екстрасистолією та пароксизмальними тахікардіями, низький рівень у випадку пацієнтів із фібриляцією передсердь та порушень провідності серця.

Перспективи подальших досліджень. Дослідити динаміку психологічних особливостей особистості та відношення до хвороби у пацієнтів із різними видами порушення ритму серця під впливом лікувальних і реабілітаційних заходів.

Список літератури

1. Pedersen SS, von Känel R, Tully PJ, Denollet J. Psychosocial 
Original research

perspectives in cardiovascular disease. Eur J Prev Cardiol. 2017;24(3):108-15. DOI: 10.1177/2047487317703827.

2. Greenman PS, Viau P, Morin F, Lapointe-Campagna MÈ, Grenier J, Chomienne MH, et al. Of Sound Heart and Mind: A Scoping Review of Risk and Protective Factors for Symptoms of Depression, Anxiety, and Posttraumatic Stress in People With Heart Disease. J Cardiovasc Nurs. 2018;33(5):16-8. DOI: 10.1097/ JCN.0000000000000508.

3. De Hert M, Detraux J, Vancampfort D. The intriguing relationship between coronary heart disease and mental disorders. Dialogues Clin Neurosci. 2018;20(1):31-40. DOI: 10.31887/ DCNS.2018.20.1/mdehert.

4. Hindricks G, Potpara T, Dagres N, Arbelo E, Bax JJ, Blomström-Lundqvist C, et al. 2020 ESC guidelines for the diagnosis and management of atrial fibrillation developed in collaboration with the European Association of Cardio-Thoracic Surgery (EACTS). Eur Heart J. 2021;42(5):373-98. DOI:10.1093/eurheartj/ehaa612.

5. Сичов ОС, Бородай АО, Солов'ян ГМ, Міхалєва ТВ. Суправентрикулярні тахікардії: сучасні методи діагностики та лікування (у фокусі оновлених рекомендацій Європейської асоціації кардіологів щодо ведення пацієнтів із суправентрикулярними тахікардіями 2019 року). Ліки України. 2020;8:11-9. DOI: https:// doi.org/10.37987/1997-9894.2020.8(244).215471.

6. Almas A, Moller J, Iqbal R, Forsell Y. Effect of neuroticism on risk of cardiovascular disease in depressed persons - a Swedish population-based cohort study. BMC Cardiovasc Disord. 2017;17(1):185-10. DOI: 10.1186/s12872-017-0604-4.

7. Ladwig KH, Goette A, Atasoy S, Johar H. Psychological aspects of atrial fibrillation: A systematic narrative review: Impact on incidence, cognition, prognosis, and symptom perception. Curr Cardiol Rep. 2020;22(11):137. DOI: 10.1007/s11886-020-01396-w.

8. Sadeghi B, Mashalchi H, Eghbali S, Jamshidi M, Golmohammadi M, Mahvar T. The relationship between hostility and anger with coronary heart disease in patients. J Educ Health Promot. 2020;9:223. DOI: 10.4103/jehp.jehp_248_20.

9. Freak-Poli R, Ikram M, Franco O, Hofman A, Tiemeier H. Depressive symptoms prior to and after incident cardiovascular disease and long-term survival. A population-based study of older persons. Depress Anxiety. 2018;35(1):18-13. DOI: 10.1002/da.22689.

10. Sin NL, Kumar AD, Gehi AK, Whooley MA. Direction of Association Between Depressive Symptoms and Lifestyle Behaviors in Patients with Coronary Heart Disease: The Heart and Soul Study. Ann Behav Med. 2016;50(4):523-32. DOI: 10.1007/s12160-016-9777-9.

11. Чабан О, Хаустова О, Асанова А, Трачук Л, Ассонов Д. Практична психосоматика: діагностичні шкали. Київ: Медкнига; 2019. $111 \mathrm{c}$.

\section{References}

1. Pedersen SS, von Känel R, Tully PJ, Denollet J. Psychosocial perspectives in cardiovascular disease. Eur J Prev Cardiol. 2017;24(3):108-15. DOI: 10.1177/2047487317703827.
2. Greenman PS, Viau P, Morin F, Lapointe-Campagna ME, Grenier J, Chomienne MH, et al. Of Sound Heart and Mind: A Scoping Review of Risk and Protective Factors for Symptoms of Depression, Anxiety, and Posttraumatic Stress in People With Heart Disease. J Cardiovasc Nurs. 2018;33(5):16-12. DOI: 10.1097/ JCN.0000000000000508.

3. De Hert M, Detraux J, Vancampfort D. The intriguing relationship between coronary heart disease and mental disorders. Dialogues Clin Neurosci. 2018;20(1):31-40. DOI: 10.31887/ DCNS.2018.20.1/mdehert.

4. Hindricks G, Potpara T, Dagres N, Arbelo E, Bax JJ, Blomström-Lundqvist C, et al. 2020 ESC guidelines for the diagnosis and management of atrial fibrillation developed in collaboration with the European Association of Cardio-Thoracic Surgery (EACTS). Eur Heart J. 2021;42(5):373-98. DOI: 10.1093/eurheartj/ehaa612.

5. Sychov OS, Borodai AO, Solov'ian HM, Mikhalieva TV. Supraventrykuliarni takhikardii: suchasni metody diahnostyky ta likuvannia (u fokusi onovlenykh rekomendatsii Yevropeis'koi asotsiatsii kardiolohiv schodo vedennia patsiientiv iz supraventrykuliarnymy takhikardiiamy 2019 roku) [Supraventricular tachycardia: modern methods of diagnosis and treatment (in the focus of the updated recommendations of the European Association of Cardiologists for the management of patients with supraventricular tachycardia in 2019)]. Liky Ukrainy. 2020;8;11-9. https://doi.org/10.37987/19979894.2020.8(244).215471. (in Ukrainian).

6. Almas A, Moller J, Iqbal R, Forsell Y. Effect of neuroticism on risk of cardiovascular disease in depressed persons - a Swedish population-based cohort study. BMC Cardiovasc Disord. 2017;17(1):185-10. DOI: 10.1186/s12872-017-0604-4.

7. Ladwig KH, Goette A, Atasoy S, Johar H. Psychological aspects of atrial fibrillation: A systematic narrative review: Impact on incidence, cognition, prognosis, and symptom perception. Curr Cardiol Rep. 2020;22(11):137. DOI: 10.1007/s11886-020-01396-w.

8. Sadeghi B, Mashalchi H, Eghbali S, Jamshidi M, Golmohammadi M, Mahvar T. The relationship between hostility and anger with coronary heart disease in patients. J Educ Health Promot. 2020;9:223. DOI: 10.4103/jehp.jehp_248_20.

9. Freak-Poli R, Ikram M, Franco O, Hofman A, Tiemeier H. Depressive symptoms prior to and after incident cardiovascular disease and long-term survival. A population-based study of older persons. Depress Anxiety. 2018;35(1):18-13. DOI: 10.1002/da.22689.

10. Sin NL, Kumar AD, Gehi AK, Whooley MA. Direction of Association Between Depressive Symptoms and Lifestyle Behaviors in Patients with Coronary Heart Disease: the Heart and Soul Study. Ann Behav Med. 2016;50(4):523-32. DOI: 10.1007/s12160-016-9777-9.

11. Chaban O, Khaustova O, Asanova A, Trachuk L, Assonov D. Praktychna psykhosomatyka: diahnostychni shkaly [Practical psychosomatics: diagnostic scales]. Kiev: Medknyha; 2019. 111 p. (in Ukrainian).

\section{Відомості про авторів}

Поліщук О. Ю. - канд. мед. наук, доцент кафедри внутрішньої медицини, фізичної реабілітації та спортивної медицини Буковинського державного медичного університету, м. Чернівці, Україна.

Амеліна Т.М. - канд. мед. наук, доцент кафедри внутрішньої медицини, фізичної реабілітації та спортивної медицини Буковинського державного медичного університету, м. Чернівці, Україна.

Жиряда Н.Я. - лікар-інтерн Буковинського державного медичного університету, м. Чернівці, Україна.

\section{Сведения об авторах}

Полищук А. Ю. - канд. мед. наук, доцент кафедры внутренней медицины, физической реабилитации и спортивной медицины Буковинского государственного медицинского университета, г. Черновцы, Украина.

Амелина Т.М. - канд. мед. наук, доцент кафедры внутренней медицины, физической реабилитации и спортивной медицины Буковинского государственного медицинского университета, г. Черновцы, Украина.

Жиряда Н.Я. - врач-интерн Буковинского государственного медицинского университета, г. Черновцы, Украина.

\section{Information about the authors}

Polishchuk O.Yu. - Doctor of Philosophy, Associate Professor of the Department of Internal Medicine, Physical Rehabilitation and Sport Medicine of Bukovinian State Medical University, Chernivtsi, Ukraine. 
Оригінальні дослідження

Amelina T.M. - Doctor of Philosophy, Associate Professor of the Department of Internal Medicine, Physical Rehabilitation and Sport Medicine of Bukovinian State Medical University, Chernivtsi, Ukraine.

Zhyriada N.Ya. - Intern of the Department of Internal Medicine and Infectious Disease of Bukovinian State Medical University, Chernivtsi, Ukraine.

Надійила до редакції 6.04.2021

Рецензент - д-р мед. наук Волочина Л.О.

(C) О.Ю. Полішук, Т.М. Амеліна, Н.Я. Жиряда, 2021 